\title{
PARA INGLÊS (E BRASILEIRO) VER
}

André Luiz Joanilho

Inicialmente escrito para um público norte-americano, Uma História do Brasil, Paz e Terra, 1998, deve ser lido pelos brasileiros. Sem a necessidade de filiação com determinadas linhas de interpretação da nossa História, Skidmore pôde apresentar uma narrativa geral sobre a nossa formação e, mais ainda, traçar uma rota para compreendê-la.

A questão fundamental para o autor é perceber como foi possível constituir uma identidade nacional num país que apresenta características de formação tão disparatadas e aí está o seu grande mérito.

Se uma das nossas maiores preocupações em relação ao estrangeiro é passar uma imagem de civilidade, este livro, justamente, nos mostra como podemos ser percebidos e compreendidos por alguém de fora, que busca ir além dos estereótipos, explicando-os. Assim, podemos perceber a extensão do que somos, ou melhor, de como somos explicados a um público de cultura média e, no caso, norte-americano.

É evidente que, se procuramos análises complexas por parte do autor, não as teremos, e aí está outro dos grandes valores do livros. Sem a necessidade de linguagem rebuscada, Skidmore apresenta um quadro claro e bastante elucidativo da nossa formação. Isto é possível justamente por estar livre de filiações acadêmicas ou linhas interpretativas da nossa História. Percebese que o texto não rende homenagens a este ou àquele pensador nacional, pois a preocupação de Skidmore é a possibilidade de síntese para um público que desconhece querelas acadêmicas, o que dá fluidez ao texto, sem cair em simplificações.

Skidmore identifica bem a nossa situação racial ao centrála na figura do mulato. Este, expoente de uma sociedade multirracial que se constituiu durante o período colonial, teve 
ascensão social limitada, mas significativa, praticamente inviabilizando a separação legal entre as raças. O racismo da elite branca se revela mais "sutil" do que o da elite norteamericana. A idéia de "branquear" a população através da imigração européia é parte constitutiva da ideologia da sociedade multirracial.

O autor percebe em parte esta trajetória, mas acredito que faltou compreender um pouco melhor o espírito da "Casa Grande" na qual a aparência é fundamental - um grande fazendeiro nunca aceitou rótulos negativos sobre a sua conduta ou condição social, logo faz de tudo para se promover e aparentar.

Desse modo, o mito multirracial não é só fruto de cruzamentos, é também formas da elite aparentar cordialidade, bondade, preocupação com os pobres e também poder, pois os mulatos, muitos filhos bastardos de grandes proprietários, não podiam ser deixados à míngua, logo lhes eram arranjadas colocações junto à administração pública, uma maneira de estender o poder da Casa Grande em direção à esfera do espaço público.

Essa expressão da nossa elite e, porque não, da nossa sociedade, é difícil de ser notada por alguém que não vivencia tal experiência. A explicação de Skidmore é bem americana: "ocorreu que uma constante carência de mão-de-obra européia nos escalões mais altos da força de trabalho brasileira deixou abertas algumas oportunidades de trabalho para negros livres, que eram bem mais numerosos no Brasil colonial do que na América do Norte colonial" e corretamente acrescenta: "não se deve concluir daí que o Brasil estava livre de preconceito" (pág. 42).

Ora, essa certa ascensão do mestiço, para Skidmore, aliviou as tensões raciais até os nossos dias, o que não é de modo algum satisfatório. É necessário um sistema ideológico e de constituição do social que assegure, além das condições econômicas, a situação racial e, no nosso caso, a situação das classes. Não que exista engano na observação do autor, mas ela não é suficiente. Um sistema que apresenta como representação social a possibilidade das diferentes culturas se 
manifestarem, a ideologia da democracia racial, são elementos constitutivos das relações interaciais.

A parte esta questão, a narrativa de Skidmore, longe de ser inédita, privilegia junto com as questões de formação, a trajetória política do nosso país e é justamente aqui que o livro se mostra muito interessante. A necessidade de síntese leva o autor a nos fornecer quadros amplos e bastante compreensivos acerca dos acontecimentos de nossa História. A análise do período militar é particularmente profícua nesse sentido. Os mais críticos verão um quadro simplificado, mas tendo em vista os objetivos da obra, o que o autor nos apresenta é uma descrição sintética sem perder o gosto explicativo.

Enfim, é uma obra que deve ser lida, pois ao evitar filiações, pode nos apresentar um painel instrutivo e de fácil leitura da nossa História. 